\title{
Left Main Coronary Artery Ostium
}

National Cancer Institute

\section{Source}

National Cancer Institute. Left Main Coronary Artery Ostium. NCI Thesaurus. Code C116172.

The opening of the left coronary artery at its origin. 